\title{
RARE METAL GRANITES AND RELATED ROCKS OF THE UKRAINIAN SHIELD
}

\author{
K. Ye. ESIPCHUK, Ye. M. SHEREMET \\ and K. I. SVESHNIKOV
}

ESIPCHUK, K. Ye.; SHEREMET, Ye. M. and SVESHNIKOV, K. I., 1993. Rare metal granites and related rocks of the Ukrainian shield. Bull. Geol. Soc. Finland 65, Part II, 131-141.

Two rare metal leucocratic granites, Perga and Kamennaya complexes, can be distinquished on the Ukrainian shield. The Perga complex consists of medium- and coarse grained, mainly porphyric, biotite, riebeckite and aegirine granites, granite porphyries, microclinites and albitites with rare metal mineralization (genthelvite, phenacite, tantalite, cassiterite and wolframite etc.). Granites from several stocks (up to $30 \mathrm{~km}^{2}$ ) in the northwestern part of the shield, situated along the fracture zone, restricted the large Korosten pluton of rapakivi granites to the northwest. The age of these granites $(\mathrm{Pb}-\mathrm{Pb}$ and $\mathrm{U}-\mathrm{Pb}$ methods on zircon and monazite) practically coincide with the age of rapakivi granites being $1750 \mathrm{Ma}$.

Within the Korosten complex of rapakivi granites we consider that zinnwaldite granites, which are characterized by fluorite and topazine mineralization, represent the final phase of pluton. These granites differ from the Perga ones by their low content of rare metals.

The Kamennaya Mogila complex lies in the southeastern part of the Ukrainian shield. It consists of biotite and muscovite-biotite, medium- and coarse-grained (also porphyric, and occasionally greisining) granites with rare metal mineralization (cassiterite, columbite, molybdenite, wolframite and beryl). Granites form several stocks $\left(5-30 \mathrm{~km}^{2}\right)$ situated $10-30 \mathrm{~km}$ to the west-northwest of the South-Kalchik gabbro-syenite-granite pluton. Granitoids in both of these complexes have similar isotopic ages (1800 Ma). Leucocratic subalkaline granites (the Novoyanisol type) are known within the pluton itself, occupying an intermediate position between the above mentioned in terms of mineral and geochemical composition.

The gabbro-syenite-granite formation of the Nearazov region has a substantial similarity to the anorthosite-rapakivi-granite formation. In this respect the relation of each of them to rare metal granites is rather remarkable. This relation is, most probably, not only spatial, but also genetic. The typical rare metal granites are situated not in the parent plutons but at some distance from them.

Key words: granites, mineral composition, chemical composition, rare earths, Ukrainian shield, Proterozoic, Ukraine.

Esipchuk, K. Ye.: Institute of Geochemistry and Physics of Minerals, Ukrainian Academy of Sciences. Palladin Av. 34, Kiev-142, Ukraine.

Sheremet, Ye. M.: Polytechnical Institute. Artem St. 58, Donetsk-66, Ukraine.

Sveshnikov, K. I.: Lvov State University. 290005 Lvov, Ukraine. 


\section{GEOLOGY OF THE STUDY AREA}

Perga and Kamennaya Mogila complexes represent leucocratic granites. These complexes are located in the Nearazov region and in the northwestern parts of the Ukrainian shield (Fig. 1). The Perga complex is in association with the Korosten gabbroanorthosite-rapakivi-granite pluton and the Kamennaya Mogila complex with the South Kalchik gabbro-syenite-granite pluton.

The Korosten pluton $\left(12,000 \mathrm{~km}^{2}\right)$ mainly consists of hornblende-biotite and biotite rapakivi granites. However, coarse layered bodies and massifs (15-1,250 $\left.\mathrm{km}^{2}\right)$ of anorthosites, gabbro anorthosites and gabbro-norites also occur within these rapakivi granites. The geophysical data indicates that some sub-horizontal acid and basic rocks alternate in this chonolithic intrusion (Sollogub et al. 1968).

Granitoids of the pluton are represented by several phases. The earliest one we assign pyroxinehornblende-rapakivi with occasional fayalite that developed in contact with gabbro-monzonites near the peripheral parts of gabbro-anorthosite massifs. The second and the main intrusive phase is represented by hornblende-biotite and biotite rapakivi granites. Several facies can be distinguished in this main phase and these facies can be differentiated from each other in terms of structure and composition. The third phase is represented by biotite granite-porphyries and syenite-porphyries that form stock-like bodies and dykes within exoand endocontacts of pluton. The fourth phase can be referred to albitized fluorite-topaz-bearing biotite granites with slightly expressed rare metal specialization (the Lezniki granites).

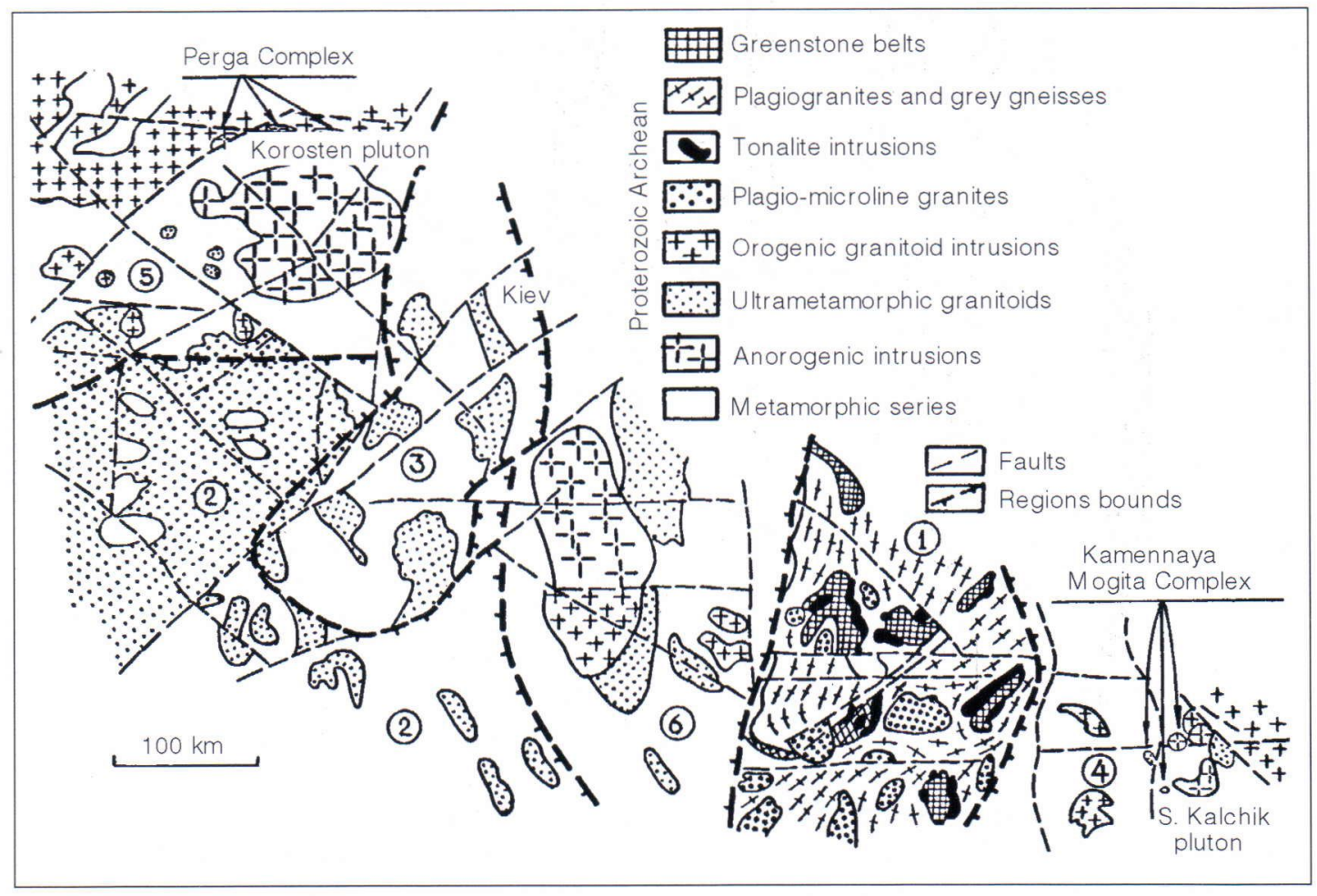

Fig. 1. Ukrainian shield, regional geological setting. Small intrusions of rare metal leucocratic granites (Perga and Kamennaya Mogila) are also indicated. Regions of the shield (numbers in circles): (1) granite-greenstone Near-Dnipro, (2) granulite-gneiss Dnistr-Bug, (3) diaphthoresic granulite-gneiss Ros-Tikish, (4) diaphthoresic granulite-gneiss Nearazov, (5) granite-gneiss North-Western, (6) granite gneiss Ingulo-Ingulets. 


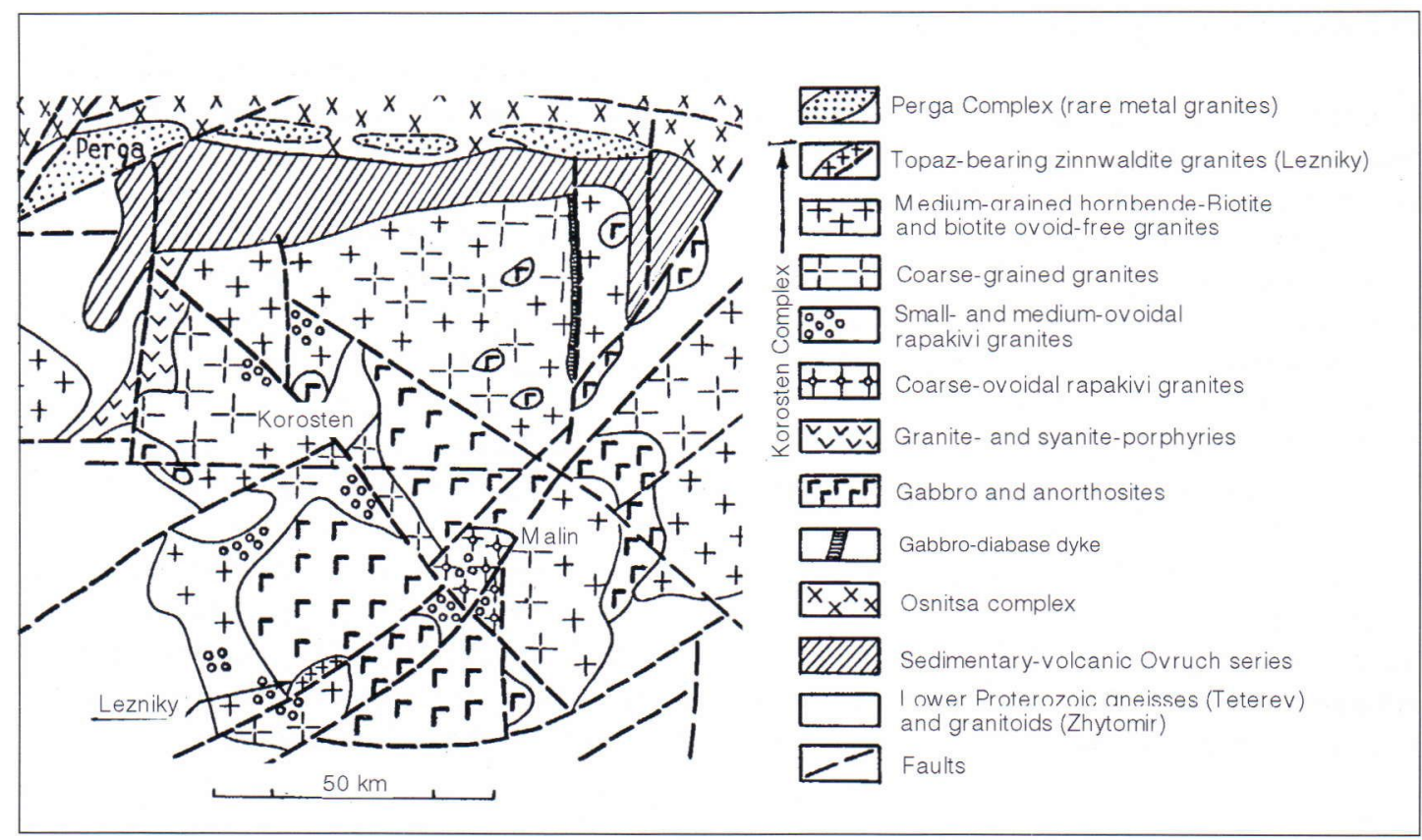

Fig. 2. Geological sketch of the Korosten pluton and Perga massifs.

Some workers consider that a typical rare metal suite of Perga granites was originated during the same phase as the rare metal suite in the Korosten complex connecting these suites with late differentiates of same magmatic source. However, considering all petrographical and geochemical data presented below the Perga granites, unlike the Lezniki ones, are an independent complex.

Granites of the Perga complex consist of several stocks in the northeast-southwest trending Sushchany-Perga tectonic zone and in the zone of the sublatitudinal South Pripyat fault (Fig. 1). The Korosten pluton and adjacent Ovrouch depression, consisting of platform volcanogenic sedimentary formations (Fig. 2), restrict the fracture zones in the north. The largest and the most investigated Perga stock is a body stretching for $30 \mathrm{~km}$ along the fracture zone with a maximum width of $12 \mathrm{~km}$ and a total area of almost $20 \mathrm{~km}^{2}$ (Fig. 3). The stock's northern part which is up to $5 \mathrm{~km}$ wide, consists of occasional leucocratic medium- and coarse-grained pegmatoid in the Khochin granites. The massifs southwestern part consists of middle-to fine-grained Lvovky granites and its southeastern parts of porphyric Sirnitsa granites. The Perga granites compose, in fact, the stock's central part by rather wide (thousands of metres) zones of intensively altered (ablitized, greisenized) granites of the types named above. Zones (more than $2 \mathrm{~km}$ wide) of cataclized granites without obvious metasomatic character are situated near the stock's periphery. Hence, gradual transition can be observed between the typical Perga granites and granites of other types that belong to this complex. This is because of superposition of tectonic and metasomatic processes. Sharp boundaries between the granites hardly exist. They are especially rare in the central part of the stock.

The country rocks of the Perga complex are Palaeoproterozoic gabbroids and granitoids of the Osnitsa and Zhitomir complexes and volcanites of the Klesovo series. Gabbroids and granitoids of the Osnitsa complex surround the Perga stock from the north and west, granitoids of the Zhitomir complex and volcanogenic-sedimentary rocks of the Ovrouch series from the south and southwest. As a rule, direct contacts between them are tectonic. Small xenoliths of porphyrites, quartz-porphyries, felsites 
and dacite-porphyries occur in Perga granites. In the cetral part of the stock the isometrically-shaped body of the Yastrebets syenites, surrouded by finegrained granites occur. Metasomatites of various compositions are also developed in the central part (feldspathic, quartz-feldspar-micaceous and micaquartz). Usually they form vein-like, up to 1-2 m thick bodies, among gneissose granites and are confined to near contact areas of rocks of various composition. Genthelvite mineralization is related to matasomatites.

The Perga granites are accompanied by the vein complex with dominant granite porphyries forming vein bodies up to a few metres thick. Such vein of aplites, fine-grained granites, microclinites and albittites are widespread.

The Lezniki granites form a stock (about $14 \mathrm{~km}^{2}$ ) in the southeastern part of the Korosten pluton approximately $10 \mathrm{~km}$ away from its peripheral part (Fig. 2). This stock is confined to the contact zone of rapakivi granites with the largest VolodarskVolynsky gabbro anorthosite massif. No large bodies of albitized and greisenized granites, like Lezniki ones, can be found in the central and

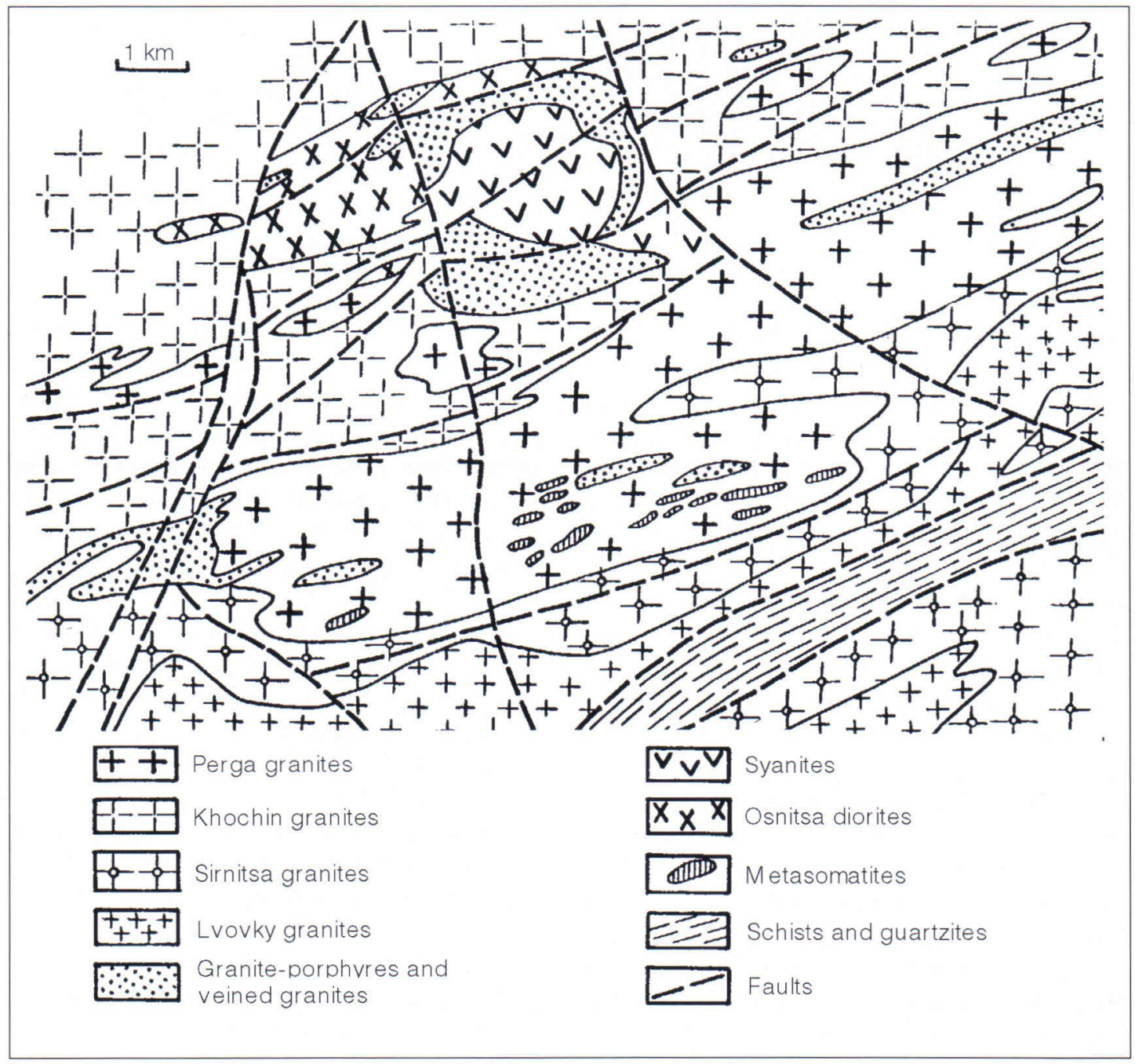

Fig. 3. Central part of the Perga massif. 


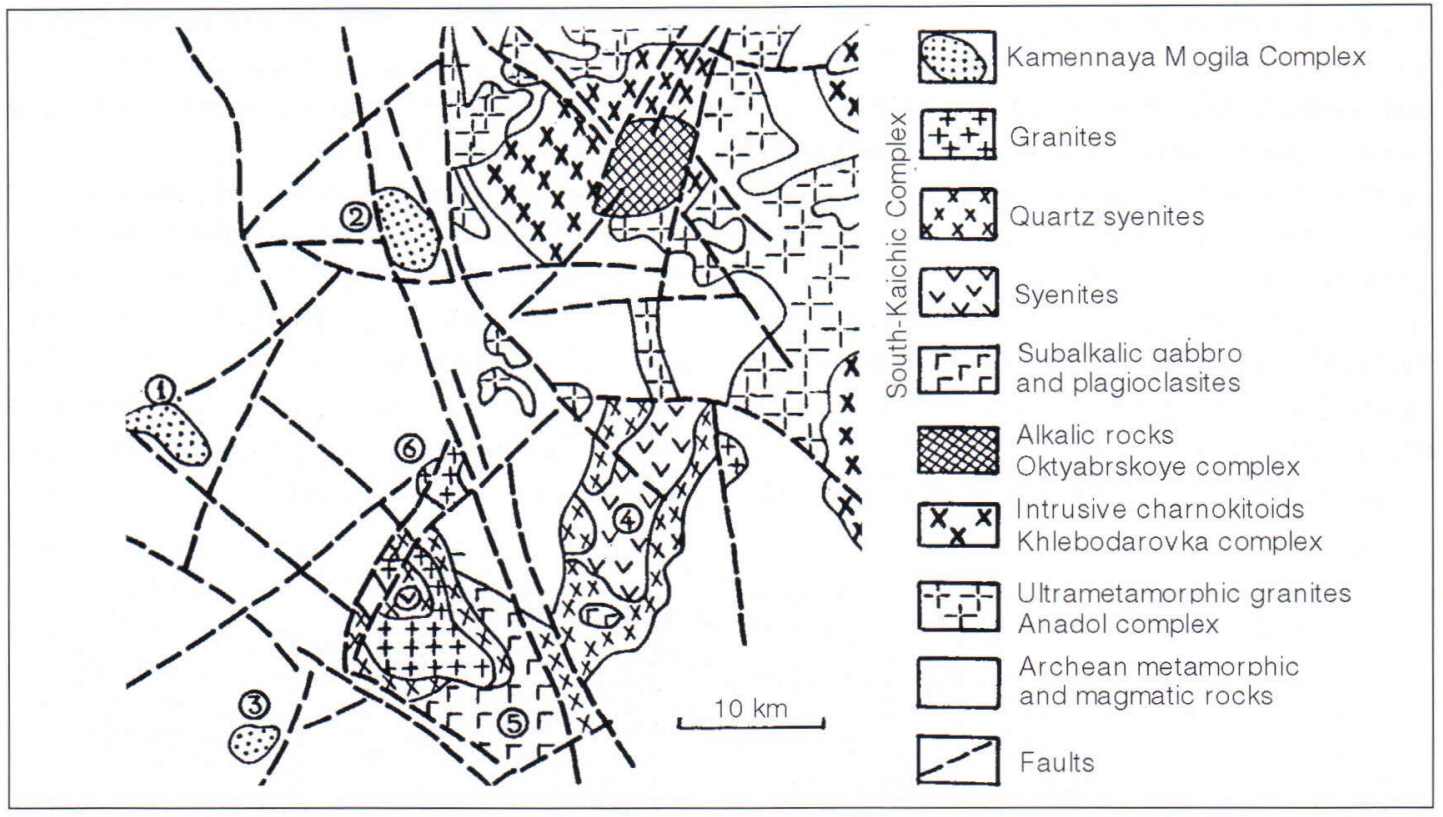

Fig. 4. Geological sketch of the Eastern-Nearazov region. Granite massifs: (1) Kamennaya Mogila, (2) Yekaterinovka, (3) Starodubovka, (4) Kremenevka, (5) Volodarskoye, (6) Novoyanisol.

northern parts of the Korosten pluton.

The South-Kalchik pluton with a total area of $330 \mathrm{~km}^{2}$ consists of two intrusions. Though connected with each other, they are characterized by individual compositions (Fig. 4). Rocks of the Volodarskoye stock are represented by four phases: gabbro-syenite, syenite, granite syenite and veined rocks. These rocks are distinctly localized. Two intrusive phases can be distinquished in the Kremenevka massif, namely gabbro-syenite and granite-syenite. The small Novoyanisol stock occurs close to Volodarskoye intrusion and consists of amphibole-biotite granites with fluorite and rare metal specialization.

Granites of Kamennaya Mogilia complex form three stocks occurring at a $10-20 \mathrm{~km}$ distance to the west and northwest of the South-Kalchik pluton. The Kamennaya Mogila stock is a ovally-shaped body with an area of $11 \mathrm{~km}^{2}$, streching from the southeast to the northwest along the Kamennaya Mogila fracture zones. This stock is confined to the intersection zone with sub-meridonial fracture. The relationship of the granites with the country gneissmigmatic section of the western Nearazov series
(Archean) is distinctly cross-cutting. The stock has a zonal structure: the central part is composed of coarse-grained biotite-granites with occasional pegmatite whereas the peripheral part is fine-grained and greisenized. Greisenization decreases with depth and at a depth of $80 \mathrm{~m}$ granites are not altered at all. At the stock's periphery aplite-pegmatoid veins are widespread.

The Yekaterinovka stock is $30 \mathrm{~km}^{2}$. Its zoning is not distinctly expressed, though it can be observed that the same arrangement of zones of metasomatism and veined aplite-pegmatoid granites exists. The Starodubovka stock $\left(4,5 \mathrm{~km}^{2}\right)$ is slightly elongated in a sublatitudinal direction.

It is shown below that a definite difference exists between granites of the Kamennaya Mogila and South-Kalchik (Novoyanisol) types and this allowed them to be assigned to different complexes.

\section{PETROGRAPHY AND MINERALOGY}

All the granites investicated are red or pink-red of various degrees. The whole rock chemistry of 
Table 1. Whole rock chemistry of granitoid samples.

GRANITOID

COMPLEX

PERGA

GRANITE TYPE

LOCALITY

Biotite Aegirin Riebeckite

Biotite

Granite-

porphyry

Perga Perga Perga Lvovky Khochin Sirnitsa Perga

$\begin{array}{lllllll}75.66 & 73.53 & 75.34 & 74.15 & 76.90 & 73.32 & 74.83 \\ 0.18 & 0.18 & 0.21 & 0.19 & 0.10 & 0.29 & 0.24 \\ 11.55 & 13.63 & 12.30 & 12.57 & 12.20 & 13.04 & 12.45 \\ 1.37 & 0.64 & 0.70 & 1.02 & 0.24 & 1.01 & 0.55 \\ 1.08 & 1.42 & 1.58 & 1.82 & 1.29 & 1.70 & 1.89 \\ 0.02 & 0.03 & 0.03 & 0.01 & 0.02 & 0.03 & 0.00 \\ 0.20 & 0.17 & 0.40 & 0.32 & 0.01 & 0.21 & 0.00 \\ 0.48 & 0.54 & 0.34 & 0.13 & 0.47 & 1.31 & 0.45 \\ 2.90 & 3.74 & 3.76 & 2.79 & 3.39 & 2.80 & 3.30 \\ 5.34 & 5.19 & 4.53 & 6.25 & 4.70 & 5.23 & 5.26 \\ 0.06 & 0.02 & 0.06 & 0.02 & 0.06 & 0.16 & 0.06 \\ 0.00 & 0.22 & 0.00 & 0.00 & 0.11 & 0.25 & 0.02 \\ 0.59 & 0.54 & 0.64 & 0.59 & 0.23 & 0.47 & 0.30 \\ 99.43 & 99.83 & 99.89 & 99.86 & 99.72 & 99.82 & 99.35\end{array}$

TRACE ELEMENTS, ppm

$\mathrm{SiO}_{2}$
$\mathrm{TiO}_{2}$
$\mathrm{Al}_{2} \mathrm{O}_{3}$
$\mathrm{Fe}_{2} \mathrm{O}_{3}$
$\mathrm{FeO}$
$\mathrm{MnO}$
$\mathrm{MgO}$
$\mathrm{CaO}$
$\mathrm{Na} \mathrm{O}_{2} \mathrm{O}$
$\mathrm{K}_{2} \mathrm{O}$
$\mathrm{P}_{2} \mathrm{O}_{5}$
$\mathrm{H}_{2} \mathrm{O}-$
l.d.t

TOTAL

$\mathrm{V}$
$\mathrm{Cr}$
$\mathrm{Co}$
$\mathrm{Ni}$
$\mathrm{Cu}$
$\mathrm{Zn}$
$\mathrm{Pb}$
$\mathrm{Sn}$
$\mathrm{Mo}$
$\mathrm{Li}$
$\mathrm{Rb}$
$\mathrm{Sr}$
$\mathrm{Ba}$
$\mathrm{Zr}$
$\mathrm{Nb}$
$\mathrm{Y}$
$\mathrm{Be}$
$\mathrm{F}$

$\begin{array}{lllllll}3 & 5 & 3 & 25 & 10 & 5 & 10 \\ 7 & 0 & 6 & 30 & 30 & 10 & 6 \\ 3 & 0 & 3 & 2 & 0 & 1 & 0 \\ 5 & 5 & 5 & 5 & 40 & 2 & 5 \\ 8 & 15 & 5 & 10 & 10 & 10 & 30 \\ 50 & 215 & 100 & 20 & 30 & 100 & 100 \\ 24 & 95 & 52 & 10 & 60 & 20 & 40 \\ 34 & 40 & 21 & 1.5 & 20 & 6 & 100 \\ 3 & 30 & 3 & 0 & 10 & 10 & 2 \\ 180 & 300 & 190 & 10 & 400 & 85 & 600 \\ 580 & 650 & 590 & 260 & 1200 & 400 & 1000 \\ 40 & 30 & 40 & 100 & 15 & 50 & 20 \\ 80 & 15 & 50 & 400 & 20 & 400 & 20 \\ 585 & 860 & 600 & 500 & 500 & 1000 & 100 \\ 135 & 120 & 150 & 10 & 50 & 30 & 100 \\ 160 & 185 & 200 & 0 & 150 & 100 & 150 \\ 6 & 20 & 6 & 0 & 1 & 7 & 10 \\ 1700 & 5000 & 2000 & 200 & 1600 & 1040 & 5000\end{array}$

$\begin{array}{lllllll}1700 & 5000 & 2000 & 200 & 1600 & 1040 & 5000\end{array}$

\section{KOROSTEN}

Biotite

Lezniky

OXIDES, \%

$\begin{array}{ll}74.77 & 76.08 \\ 0.22 & 0.16 \\ 12.02 & 11.78 \\ 1.21 & 0.81 \\ 1.08 & 1.00 \\ 0.02 & 0.02 \\ 0.00 & 0.24 \\ 0.79 & 0.90 \\ 3.10 & 3.18 \\ 5.76 & 4.82 \\ 0.00 & 0.00 \\ 0.00 & 0.00 \\ 0.69 & 0.50 \\ 99.66 & 99.49\end{array}$

$\begin{array}{lll}71.80 & 75.22 & 74.11 \\ 0.13 & 0.03 & 0.07 \\ 14.10 & 13.50 & 13.60 \\ 1.10 & 0.45 & 0.25 \\ 2.40 & 0.35 & 1.08 \\ 0.04 & 0.01 & 0.02 \\ 0.20 & 0.16 & 0.16 \\ 0.90 & 0.68 & 0.68 \\ 3.70 & 5.16 & 4.52 \\ 3.70 & 3.30 & 3.90 \\ 0.10 & 0.08 & 0.00 \\ 0.00 & 0.00 & 0.00 \\ 1.30 & 0.64 & 0.87 \\ 99.47 & 99.58 & 99.26\end{array}$

Biotite

Kamennaya Mogila
KAMENNAYA MOGILA SOUTH-KALCHIK

Hornblende-biotite

Kalchik

$\begin{array}{ll}71.30 & 76.84\end{array}$

$0.33 \quad 0.04$

$\begin{array}{ll}13.53 & 12.21\end{array}$

$0.53 \quad 0.19$

$2.88 \quad 0.72$

$0.03 \quad 0.00$

$\begin{array}{ll}0.08 & 0.24\end{array}$

$\begin{array}{ll}1.56 & 0.34\end{array}$

$3.52 \quad 3.14$

$4.96 \quad 5.48$

$0.15 \quad 0.06$

$0.10 \quad 0.00$

$0.16 \quad 0.36$

$99.13 \quad 99.62$

$\begin{array}{ll}7 & 3 \\ 5 & 5 \\ 3 & 3 \\ 5 & 5 \\ 5 & 5 \\ 30 & 80 \\ 66 & 52 \\ 3 & 5 \\ 3 & 4 \\ 110 & 46 \\ 270 & 380 \\ 50 & 50 \\ 250 & 130 \\ 440 & 450 \\ 45 & 50 \\ 80 & 85 \\ 6 & 6 \\ 1800 & 1800\end{array}$

$\begin{array}{lllll}4 & 3 & 3 & 3 & 6 \\ 6 & 8 & 5 & 5 & 12 \\ 3 & 0 & 3 & 3 & 3 \\ 5 & 5 & 5 & 0 & 5 \\ 5 & 30 & 7 & 5 & 5 \\ 100 & 30 & 30 & 30 & 10 \\ 70 & 70 & 76 & 76 & 13 \\ 37 & 14 & 21 & 14 & 7 \\ 1 & 21 & 1 & 210 & 170 \\ 960 & 66 & 97 & 180 & 40 \\ 830 & 450 & 520 & 600 & 90 \\ 120 & 30 & 30 & 400 & 200 \\ 110 & 30 & 50 & 40 & 40 \\ 150 & 120 & - & 20 & 30 \\ 50 & 60 & - & 4 & 1 \\ 90 & 100 & - & 5 & 3 \\ 20 & 4 & 8 & 10 & 3 \\ 3000 & 2400 & 1500 & 220 & 90\end{array}$


ganitoid samples are presented in Table 1. Granites have medium- to coarse-grained porphyric structure and massive texture. However, in some varieties of the altered Perga granites the texture is banded. The typical Perga granite has the following mineral composition: microcline-perthite $45-50 \%$, albite or albite oligoclase 5-10\%, quartz 33-37\%, mica up to $8 \%$. Depending on the composition of dark-coloured minerals, annite, siderophyllite (the most widespread), aegirine, arfvedsonite and riebeckite can also be distinquished in the Perga granites. Secondary minerals are muscovites, apophyllites, cryolites and kaolinites.

The Lvovky granite, represented in marginal facies of the Perga massif, is predominantly fineand medium-grained. The Sirnitsa granite is characterized by porphyric structure and massive texture with a lesser degree of ablitization whereas the Khochin granite is coarse grained and pegmatoid here and there. Bluish, bluish-grey and lilac quartz can be observed in all of the above mentioned granites; constantly in the Sirnitsa and Khochin granites, sporadically in the Lvovky granites whereas in the Perga granites only within small parts adjacent to the zones of ore-bearing metasomatites.

The Lezniki granite (see fig. 1 for location) is rather homogeneous in its composition and structure. In comparison with Perga one, the Lezniki granite is characterized by the higher content of microcline-perthite (up to $60 \%$ ) with very low content of dark-coloured minerals, represented almost entirely by annite (up to $20 \%$ ).

Granites of Perga complex are characterized by a wide spectrum of accessory minerals. The following minerals are among them: zircon, fluorite, cassiterite, thorite and ferrithorite, molybdenite, columbite, bastnaesite, haematite, martite, leucoxene, galenite, sphalerite, phenacite, genthelvite, gahnite etc. The most widespread are metamictic zircon, fluorite and thorite but their distribution is extremely irregular. The coarsegrained pegmatoid granites are poor in accessory minerals but areas of intense albitization, greisenization and silicification are highly enriched in such minerals.

In microcline of the Perga granites the abundance of anorthite component is not more than $1 \%$ and

Table 2. Biotite analyses.

\begin{tabular}{llllllll} 
LOCALITY & Perga & & & $\begin{array}{l}\text { Kamennaya } \\
\text { Mogila } \\
\text { km-16 }\end{array}$ & $\begin{array}{l}\text { Yakater- } \\
\text { inovka } \\
\text { y-1 }\end{array}$ & $\begin{array}{l}\text { Lezniky } \\
\text { Lz-5 }\end{array}$ & $\begin{array}{l}\text { South- } \\
\text { Kalchik } \\
\text { wp-1 }\end{array}$ \\
& 18 & $21 / 1$ & 1 & & & & \\
$\mathrm{SiO} 2$ & 36.38 & 36.90 & 37.14 & 36.20 & 34.30 & 34.20 & 33.92 \\
$\mathrm{TiO}_{2}$ & 2.02 & 2.90 & 2.68 & 1.10 & 1.20 & 2.10 & 3.31 \\
$\mathrm{Al}_{2} \mathrm{O}_{3}$ & 14.02 & 14.00 & 11.64 & 20.10 & 20.60 & 16.40 & 15.87 \\
$\mathrm{Fe}_{2} \mathrm{O}_{3}$ & 5.38 & 5.10 & 10.01 & 9.00 & 6.00 & 5.90 & 2.13 \\
$\mathrm{FeO}$ & 25.89 & 25.20 & 21.45 & 18.00 & 23.30 & 25.90 & 30.03 \\
$\mathrm{MnO}$ & 0.32 & 0.30 & 0.36 & 0.40 & 0.30 & 0.20 & 0.35 \\
$\mathrm{MgO}$ & 0.43 & 1.00 & 1.12 & 0.70 & 0.50 & 0.50 & 2.61 \\
$\mathrm{CaO}$ & 1.23 & 0.10 & 0.05 & 0.10 & 0.01 & 0.00 & 0.42 \\
$\mathrm{Na}{ }_{2} \mathrm{O}$ & 1.10 & 1,10 & 0.40 & 0.90 & 0.20 & 0.20 & 0.15 \\
$\mathrm{H}_{2} \mathrm{O}$ & 7.21 & 7.90 & 8.71 & 8.00 & 8.70 & 9.10 & 7.60 \\
$\mathrm{H}_{2} \mathrm{O}$ & 4.98 & 3.80 & 4.04 & 3.60 & 3.90 & 3.70 & 3.55 \\
$\mathrm{~T}_{\mathrm{T}}$ & 1.09 & 2.30 & 3.10 & 2.10 & 0.80 & 2.40 & 0.08 \\
& 99.59 & 99.63 & 99.40 & 99.32 & 99.37 & 99.59 & 99.99 \\
& & & & & & & \\
\hline
\end{tabular}


albite ranges from $18 \%$ to $35 \%$. An elevated abundance of albite is related to alkaline metasomatosis. Microcline in Perga granite is extremely high in $\mathrm{Rb}$ (2550 ppm) and Cs (4 ppm) compared with microcline in Lezniki granite $(\mathrm{Rb}$ 890 ppm, Cs 2 ppm).

Micas of rare metal granites are represented first of all by the annite-siderophyllite series (Table 2) and characterized by high $\mathrm{Fe} /(\mathrm{Fe}+\mathrm{Mg})$. Micas in the Perga biotite granites are typical annite with $\mathrm{Al}_{2} \mathrm{O}_{3}$ abundances of $11.64 \%-14.02 \%$ and iron oxide totals of $30.30 \%-31.27 \%$. In the aegirine and riebeckite-arfvedsonite Perga granites, the micas have lower $\mathrm{Al}_{2} \mathrm{O}_{3}(7.18 \%-10.26 \%)$ but higher $\mathrm{TiO}_{2}$ (3.0\%-3.42\%) content (Buchinskaya and Nachayev 1990). In the Sirnitsa, Khochin and Lvovky granites, and also in granite porphyries, biotites have the lowest $\mathrm{Fe} /(\mathrm{Fe}+\mathrm{Mg})$ for these rock series, similar to that of micas in granitoids of the Korosten complex (Lichak 1983).

Micas of the Kamennaya Mogila are represented mainly by siderophyllite with $\mathrm{Al}_{2} \mathrm{O}_{3}$ contents of more than $20 \%$. More furruginous biotite was separated from granites of the Yekaterinovka massif (Table 2). The South-Kalchik granites contain the most magnesian mica (up to $2.61 \% \mathrm{MgO}$ ), it is also characterized by an elevated content of $\mathrm{TiO}_{2}$ $(3.31 \%)$, low content of $\mathrm{K}_{2} \mathrm{O}(7.60 \%)$ and low $\mathrm{F}$ $(0.08 \%)$ abundances.

The metasomatically altered Perga granites quite often contain lithium micas (protolithionite and lithium phengite-muscovite) (Buchinskaya and Nachayev 1990). Inside large bodies of the Perga metasomatites and also in greisenized areas of pegmatites of the Kamennaya Mogila and Yekaterinovka massifs lithium micas, ferruginous lepidolite and zindwaldite occur. The biotites are also characterized by very high abundances of $\mathrm{Rb}$ (over $6000 \mathrm{ppm}$ in Perga and up to $5000 \mathrm{ppm}$ in the Kamennaya Mogila granites) and Cs (more than $200 \mathrm{ppm}$ ). Contents of these two elements in biotites from the Lezniki granites are $3000 \mathrm{ppm}$ and 40 ppm, respectively.

All three massifs of Kamennaya Mogila complex are composed of the same type of coarse- to medium-grained porphyritic granites of the following mineral composition: microcline and microclineperthite $30-40 \%$, albite and albite-oligoclase 25 $30 \%$, quarz $32-35 \%$, biotite $2-7 \%$ and muscovite $2-$ $10 \%$. In greisenized varieties of granites muscovite abundance increases up to $15-20 \%$ and in quartzmuscovite-fluorite greisens up to 50-80\%. Porphyric phenocrysts up to $3-4 \mathrm{~cm}$ form microcline and microcline-perthite with incomplete lattice structure of the chess-spotted type. Microcline from all types of rare metal granites are characterized by very low natural and X-ray thermoluminescence (Rokachuk 1988). Rb and Cs abundances in microcline from the Kamennaya Mogila granites are much lower ( $\mathrm{Rb} 1640 \mathrm{ppm}, \mathrm{Cs} 1.2 \mathrm{ppm}$ ) than in microcline of the Perga granites. Abundances of these elements in alkalic felds par from the South-Kalchik granites are also very low (Rb 500 ppm,Cs 1 ppm). One special peculiarity of the South-Kalchik granites is the the presence of high-ferruginous amphibole related to ferrohastingsite. Amphibole is absent in the Kamennaya Mogila granites.

Muscovite in rare metal granites has an elevated $\mathrm{Fe}$ content $\left(\mathrm{Fe}+\mathrm{Fe}_{2} \mathrm{O}_{3}\right.$ more than 9\%) with predominance of $\mathrm{Fe}^{2+}$ over $\mathrm{Fe}^{3+}$. In muscovite from greisenized granites and greisens $\mathrm{Fe}^{2+} / \mathrm{Fe}^{3+}$ is reversed and the total $\mathrm{Fe}$ contents are moderate. Zircon in Kamennaya Mogila granites is semitransparent, yellow and it forms prismatically bipyramidal crystals of zircon type with proelongation close 2 . Zircon usually has zonal structure metamict core. Metamictic zircon of the Perga granites forms rather coarse crystals of prismatic and bipyramidal habit and also irregular yellow, brown reddish brown and grey grains. High $\mathrm{HfO}_{2}(3-5 \%)$ and heavy REE contents are characteristic of its composition.

Fluorite is represented by several generations. Green fluorite, forming irregular separations (up to $0.5 \mathrm{~mm}$ ) between grains is characteristic of the early stages of matasomatic transformation; the distinctive feature of this fluorite is predominance of heavy rare-earth elements in its composition. In greisens and pegmatites purple-violet fluorite exists, and in the most low temperature metasomatites and hydro-thermolites a light violet-pink with predominance of light REEs in its composition. 


\section{PETROCHEMISTRY, GEOCHEMISTRY AND GEOCHRONOLOGY}

According to the chemical composition rare metal granites of the Ukrainian shield are assigned to subalkaline leucocratic granites of $\mathrm{K}-\mathrm{Na}$ series. They are characterized by high $\mathrm{SiO}_{2}$ contents ( 71.80 $76.90 \%$ ), sums of alkaline oxides in the range of $7.40-10.12 \%$, predominance of Fe over $\mathrm{Mg}(\mathrm{Fe} /$ $\mathrm{Mg}=0.81-0.95)$ and low $\mathrm{CaO}$ abundances (0.34. $0.90 \%$ ). As a rule, $\mathrm{K}_{2} \mathrm{O}$ predominates over $\mathrm{Na}_{2} \mathrm{O}$. According to the general chemical composition these granites do not differ particularly from granites of the final stages of the Korosten (Lezniki) and South-Kalchik complexes. However, their difference concerning abundances of trace elements is rather noticeable.

First of all, all rare metal granites, apart from Lvovky granites, are characterized by high $\mathrm{F}$ contents (up to $5000 \mathrm{ppm}$ ). In the Lezniki granites of the South-Kalchik complex F contents are 1800 ppm, and in granites of the South-Kalchik complex it ranges from only 90 to $220 \mathrm{ppm}$ (see Table 1). Granites of the Perga and Kamennaya Mogila complexes are distinquished by high contents of $\mathrm{Sn}$ (31-100 ppm), high abundance of Li (600-690 ppm), Be (up to $20 \mathrm{ppm}$ ), Y (up to $200 \mathrm{ppm}$ ) and $\mathrm{Rb}$ (up to $1200 \mathrm{ppm}$ ). In the Lezniki granites of the
Korosten complex contents of $\mathrm{Sn}$ is 3-5 ppm, $\mathrm{Li}$ 46110 ppm, Be 6 ppm, Y 80-85 ppm and Rb 270-380 $\mathrm{ppm}$. The South-Kalchik granites are distinquished by high contents of Mo (up to $210 \mathrm{ppm}$ ), high $\mathrm{Sr}$ abundances (200-400 ppm) and low contents of $\mathrm{Zr}$ (20-30 ppm), Nb (1-4 ppm) and Y (3-5 ppm).

High abundances of rare metal alements (REE) are characteristic of the rare metal granites investigated. In granites of other complexes (especially the gabbro-syenite-granite of the SouthKalchik complex) REE abundances are much lower (Table 3). The rare metal Perga granites have the highest abundance of heavy lanthanoids that differ them from the Lezniki granites of the Korosten complex.Chondrite-normalized REE plots (Fig. 5) show very large negative anomalies in the rare metal Perga and Kamennaya Mogila granites whereas in the Lezniki granites and especially in the South-Kalchik granites these anomalies are much lower.

Skobelev (1987) investigated lead isotope content in some samples of zircon from metasomatically altered granites and quartz-feldspar metasomatites of the Perga zone. According to his data, an age of $1675 \pm 45 \mathrm{Ma}$ was obtained reflecting the time when metasomatic process took place. Shcherbak et al. (1989) dated zircon from the Perga granites and obtained an age of 1760 Ma that practically coincides

Table 3. Rare-earth elements in granites (ppm)

\begin{tabular}{|cllll|}
\hline GRANITE TYPE & Perga & $\begin{array}{l}\text { Kamennaya } \\
\text { Mogila }\end{array}$ & Lezniky & $\begin{array}{l}\text { South- } \\
\text { Kalchik }\end{array}$ \\
SAMPLE NR & 6 & 111 & $2 \mathrm{Lz}$ & Sk \\
$\mathrm{La}$ & 95 & 119 & 110 & 7.6 \\
$\mathrm{Ce}$ & 150 & 152 & 201 & 15.0 \\
$\mathrm{Sm}$ & 9.1 & 24 & 17.1 & 2.2 \\
$\mathrm{Eu}$ & 0.2 & 0.18 & 0.4 & 0.2 \\
$\mathrm{~Tb}$ & 2.6 & 3.46 & 0.8 & 0.3 \\
$\mathrm{Yb}$ & 23 & 27 & 7.8 & 0.5 \\
$\mathrm{Lu}$ & 3.2 & 3.00 & 1.7 & 0.3 \\
& & & & \\
\hline
\end{tabular}


with the age values of rapakivi-granites (1760 Ma) and granite-porphyries (1770 Ma) of the Korosten complex. The U-Pb dating for zircon from the Kamennaya Mogila granites obtained an age of $1800 \pm 20 \mathrm{Ma}$ that is approximately the same age obtained for granitoids of the South-Kalchik complex (Esipchuk et al., 1992).

\section{CONCLUSIONS}

On petrographical and geochemical grounds the Perga and Kamennaya Mogila granites are assigned to the typical rare metal granites of lithium-fluoric type (Kovalenko 1977). Ore mineralization in the Kamennaya Mogila granites is represented by quartz-fluorite veins with cassiterite and also by metasomatites with columbite, monzanite and beryls. One can find molybdenite in pegmatite and quartz veins, albitized granites and silicified migmatites. In greisenized granites, veined pegmatites and aplite-like granites columbite, tantalite, zircon and beryl also occur.

The Perga granites are first of all characterized by the development of quartz-feldspathic and quartzmicaceous metasomatites with particular mineralization of cassiterite, phenacite, columbite, zircon, bastnaesite, wolframite, molybdenite,

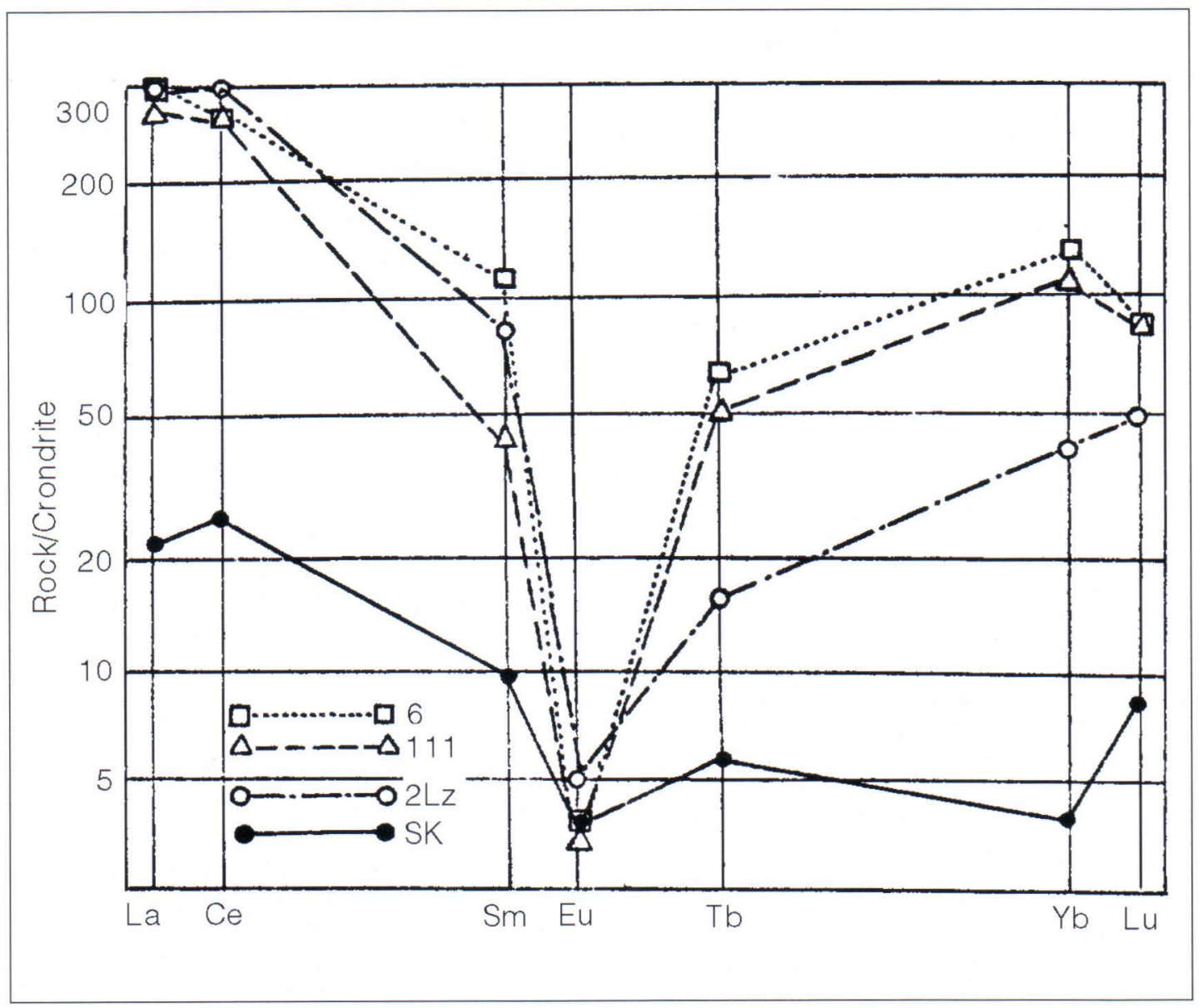

Fig. 5. Chondrite normalized REE patterns for granites investigated. Samples: $6=$ Perga, $111=$ Kamennaya Mogila, $2 \mathrm{Lz}=$ Lezniky, $S K=$ South-Kalchik. 
genthelvine. Sn and W occurences of cassiteritequartz ore formation and alluvial cassiterite placers were also discovered within the Syshchany-Perga zone (Metalidi and Nechayev 1983). There are several hypothesis on the genesis of the granites of metasomatic origin which we do not discuss in this paper. However, we consider that these granites are undouptedly magmatic formations.

Kovalenko (1977), who investigated rare metal granites of Zabaikalye, Mongolia, Nigeria and also other regions, considered that rare metal granites were derived from crustal granite magmas of alaskitic composition. F abundance in them plays an important role. During crystallization magmas unsaturated with $\mathrm{F}$ generate rare metal granites of standard geochemical type but F-saturated magmas develop rare metal granites of the lithium-fluoric type. Crystallization of lithium-fluoric granites mainly took place under hypabyssal and near-surface conditions during repeated deroofing over the magmatic source, pressure lowering and changes of acidity-alkalinity. During magma crystallization residual melts were enriched in $\mathrm{Li}, \mathrm{Rb}, \mathrm{Sn}$ and some other elements. Afterwards elements such as W, Pb and $\mathrm{Zn}$ were transfered to the fluid phase. During the whole crystallization process of lithium-fluoric granites $\mathrm{Nb}$, Ta and $\mathrm{Hf}$, abundances in the melts were high. The composition of residual fluid was enriched in $\mathrm{H}_{2} \mathrm{O}, \mathrm{Li}$ and $\mathrm{K}$ and silica, e.g. in those components which later took part in granitic greisenization.

We share the opinion of those researchers who consider rare metal granites of lithium-fluoric type (to which referred granites of Perga and Kamennaya Mogila complexes belong on the basis of geological, petrological, mineralogical and geochemical characteristics) to be derived from high-fluoric granite magmas, generated in the continental crust under the influence of abyssal fluid heat flows, and crystallized in an anorogenic situation. Formation of anorogenic gabbro-anorthosite-rapakivi-granite and gabbro-syenite-granite plutons predates their formation, although primary magmatic sources of them both were different.

IGCP Project 315 (Rapakivi Granites and Related Rocks) Publication Nr 24.

Rokachuk, T. A. 1988. Petrological aspects of luminescence of feldspars. Nauka dumka, Kiev 1988. 200 pp.

Shcherbak, N. P., Artemenko, G. V. and Barnytsky, Ye.N. 1989. Nauka dumka, Kiev 1988. 144 pp.

Skobolev, V. M. 1987. Petrochemistry and geochronology of Precambrian formations of the North-Western district of the Ukrainian shield. Nauka dumka, Kiev 1987. 140 pp.

Sollogub, V. B., Kalyuzhnaya, L. T. and Chekunov, A. V. 1968. Abyssal structure of the earth's crust in the Korosten pluton area according to data of seismic investigations. Geophys. G. 25, 31-45.

Tauson, L. V. 1977. Geochemical types and potential orebearing of granitoids. Nauka, Moscow 1977. $279 \mathrm{pp}$

Zinchenko, O. V. and Pavlishing V.I. 1980. Constitutional peculiarities of micas from metasomatites of Ukraine. Mineral. zb. of the Lvov Geol. Soc. 34, 4753. 